University for Business and Technology in Kosovo

UBT Knowledge Center

Oct 28th, 9:00 AM - Oct 30th, 5:00 PM

\title{
Analysis of the Mobile Market in 2014 in Macedonia, Recommendations for Better Development and Improved Quality of Mobile Services
}

\author{
Arsov Boris \\ Agency for Electronic Communications, boris.arsov@aec.mk \\ Trajkovski Vasko \\ Agency for Electronic Communications
}

Follow this and additional works at: https://knowledgecenter.ubt-uni.net/conference

Part of the Communication Commons, and the Computer Sciences Commons

\section{Recommended Citation}

Boris, Arsov and Vasko, Trajkovski, "Analysis of the Mobile Market in 2014 in Macedonia, Recommendations for Better Development and Improved Quality of Mobile Services" (2016). UBT International Conference. 49.

https://knowledgecenter.ubt-uni.net/conference/2016/all-events/49

This Event is brought to you for free and open access by the Publication and Journals at UBT Knowledge Center. It has been accepted for inclusion in UBT International Conference by an authorized administrator of UBT Knowledge Center. For more information, please contact knowledge.center@ubt-uni.net. 
Book of Proceedings

International Conference on Computer Science and Communication Engineering

\title{
Analysis of the Mobile Market in 2014 in Macedonia, Recommendations for Better Development and Improved Quality of Mobile Services
}

\author{
Arsov Boris, Trajkovski Vasko \\ Agency for Electronic Communications, $21^{\text {st }}$ Dimitar Vlahov - Kej, 1000 Skopje, \\ Republic of Macedonia \\ boris.arsov@aec.mk
}

\begin{abstract}
In order to regulate the electronic communications market in a systematic way, the Agency for Electronic Communications, as a regulatory body in the field of electronic communications, has strongly set issues and targets to be achieved. The Agency has guidelines how to achieve the issues of a competitive market where conditions for using the electronic communications services with best quality and best prices are going to be created for the end users.
\end{abstract}

Keywords: prices, customers, mobile market, mobile operator, competition, revenue

\section{Introduction}

In order to confirm the strategic direction for the development of electronic communications market in Macedonia, the Agency has made an assessment of the regulatory progress that was performed in a period of one year, according to the received data and their analysis. This assessment can provide a clear picture of the development of the market and will present the current market situation in Macedonia from technical, financial, operational and competitive standpoint.

\section{Mobile market}

In 2014 four companies provided public available telephone services in the public mobile communication network for national and / or international traffic, and they were:
1. T-Mobile Skopje
2. ONE-Operator Skopje
3. VIP Operator Skopje
4. Albafon Skopje. (Mobile virtual network operator) (VMO)

From the table 1, we can see the percentage decrease of $0.57 \%$ in the number of active subscribers in mobile telephony in 2014, compared to the previous year. It is obvious that the majority of residential subscribers prefer to use prepaid services rather than using postpaid services. The number of postpaid subscribers is increasing and residential postpaid subscribers grew by $9.47 \%$ for a one year period, business subscribers grew by $8.00 \%$ for the same period. On the other hand, we can notice a decrease in the number of SMS messages compared to 2013, which is $19.88 \%$, while the total number of MMS messages sent in 2014 has an increasing line of $4.88 \%$ over the previous year. 
Analysis of the Mobile Market in 2014 in Macedonia, Recommendations for Better Development and Improved Quality of Mobile Services

The total traffic minutes are increased from $7.95 \%$ in 2014 compared to 2013 . We can see that from the total traffic realized in 2014 there is a growth, compared to the previous year, in the traffic to all destinations, with the exception of traffic in the own mobile network, which has dropped by $0.01 \%$ and traffic to the networks in the foreign countries, where it has dropped by $1,74 \%$. It is important to note that the highest growth is recorded in the traffic towards the other mobile networks in RM, which is $54.70 \%$.

Table 1: Indicators of the mobile market - Retail, where the data are given for 2014 and 2013 and the difference given in $\%$.

\begin{tabular}{|l|r|r|r|}
\hline & $\mathbf{2 0 1 4}$ & $\mathbf{2 0 1 3}$ & \multicolumn{2}{|c|}{$\begin{array}{l}\text { Difference } \\
\text { (\%) }\end{array}$} \\
\hline $\begin{array}{l}\text { Residential prepaid } \\
\text { subscribers }\end{array}$ & 1.234 .726 & 1.329 .512 & $-0,57$ \\
\hline $\begin{array}{l}\text { Residential postpaid } \\
\text { subscribers }\end{array}$ & 697.954 & 637.594 & $-7,13$ \\
\hline $\begin{array}{l}\text { Business post paid } \\
\text { subscribers }\end{array}$ & 291.759 & 270.144 & 8,00 \\
\hline $\begin{array}{l}\text { Number of active } \\
\text { subscribers in mobile } \\
\text { telephony }\end{array}$ & 2.224 .439 & 2.237 .250 & $-0,57$ \\
\hline $\begin{array}{l}\text { Number of SMS } \\
\text { messages }\end{array}$ & 322.190 .794 & 402.158 .557 & $-19,88$ \\
\hline $\begin{array}{l}\text { Number } \\
\text { messages }\end{array}$ & 997.902 & 951.487 & 4,88 \\
\hline $\begin{array}{l}\text { Total number of calls in } \\
\text { own mobile network }\end{array}$ & 1.957 .144 .963 & 2.050 .441 .388 & $-4,55$ \\
\hline $\begin{array}{l}\text { Total number of calls to } \\
\text { other mobile networks } \\
\text { in RM }\end{array}$ & 598.226 .449 & 447.427 .097 & 33,70 \\
\hline $\begin{array}{l}\text { Total number of calls to } \\
\text { fixed networks in RM }\end{array}$ & 59.576 .085 & 52.357 .464 & 13,79 \\
\hline $\begin{array}{l}\text { Total number of calls to } \\
\text { networks in foreign } \\
\text { countries }\end{array}$ & 14.204 .276 & 15.704 .232 & $-9,55$ \\
\hline $\begin{array}{l}\text { Total number of calls in } \\
\text { mobile networks }\end{array}$ & 2.629 .151 .773 & 2.565 .930 .181 & 2,46 \\
\hline
\end{tabular}

Regarding the total number of calls in mobile networks in 2014 we can see growth by $2.46 \%$ over the previous year. Regarding the number of calls divided by destinations, we may notice a drop in the number of calls to the own mobile network to $4.55 \%$ and the number of calls to networks in foreign countries to $9.55 \%$, while in other destinations there is a growth which is the largest regarding the number of calls towards the other mobile networks in RM and it is $33.70 \%$. 
Figure 1: Share of the operators in the revenues from providing mobile communication services (retail level) in 2014

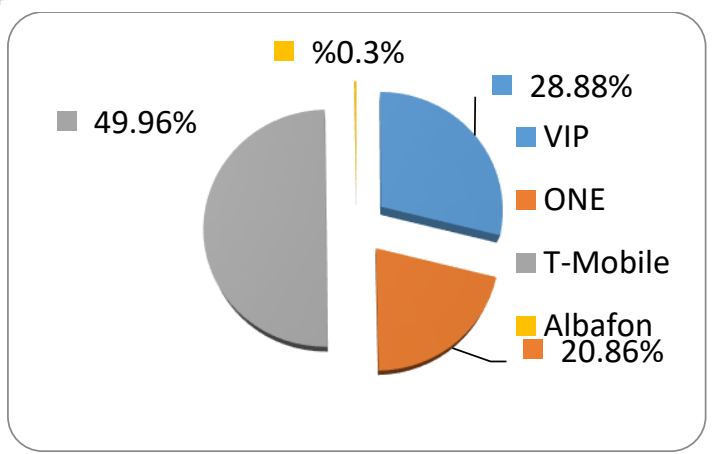

The chart 1 shows the market share of the mobile operators in Macedonia in the revenues generated from the provision of the mobile communications services in the retail market for 2014. From the figure 1 it can be seen that the largest market share has the mobile operator T-Mobile with $49.96 \%$, next is the VIP operator with $28,88 \%$, the ONE operator with $20.86 \%$ and the Albafone with $0.30 \%$. The Market shares are calculated on the total income and it is the sum of revenues: service for call from a monthly subscription, the data transmission from the terminal equipment, SMS, the MMS, from roaming (traffic, SMS and data) and the other revenue.

Figure 2: Share of the operators in revenues from providing mobile communications services (wholesale level) in 2014

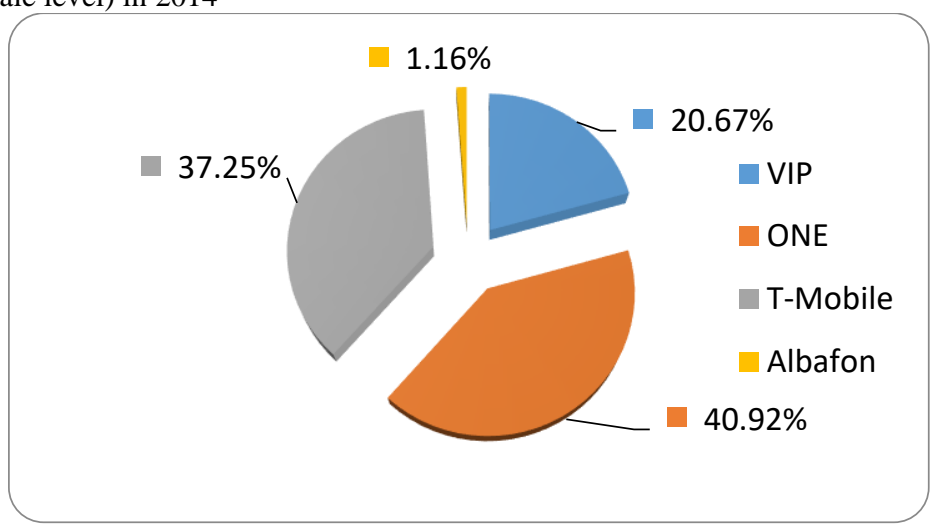

The Chart 2 shows the market share of the mobile operators in Macedonia in the revenues generated from the provision of mobile communications services in the wholesale market for 2014 . From the figure 2 it can be seen that the largest market share has the mobile operator ONE operator with $40.92 \%$, next is the T-Mobile with $37.25 \%$, the VIP operator with $20.67 \%$ and the Albafone with $1.16 \%$. The Market shares are calculated on the total income and it is the sum of revenues: service for call termination, national roaming, transit traffic, termination of SMS, termination of MMS and roaming by foreign subscribers located in Macedonia.

In accordance with the total revenues achieved in the market for electronic communications that are realized by the mobile operators, a drop of $6.37 \%$ in 2014 may be noticed in comparison to 2013. In 2014, the total revenues from provision of public available telephone services on public 
Analysis of the Mobile Market in 2014 in Macedonia, Recommendations for Better Development and Improved Quality of Mobile Services

mobile communication network for national / international traffic were 7,941,635,000.00 denars or 129,132,276.42 euro, while in 2013 they were $8,481,560,000.00$ denars or 137,911,544.72 euro. As one of the most widely used packet of services that the most operators have been exercising revenue is the packet named Relax Surf postpaid tariff model.

The Relax Surf postpaid tariff model for the residential users of telecommunications service offers:

- Unlimited calls in the network of the mobile operator;

- Unlimited 3G internet;

- Free minutes for calls to other networks;

- Free SMS messages;

Table 2 shows the prices and specifications of the offered services provided by the official websites of the operators. It must be noted that the differences in the prices between the operators are small and they do not have any differences from the data shown in Table 2.

Table 2: Packets and Prices of the mobile services that are usually used by the customers

\begin{tabular}{|c|c|c|c|c|}
\hline & $\begin{array}{l}\text { Relax Surf } \\
\text { S }\end{array}$ & $\begin{array}{l}\text { Relax Surf } \\
\text { M }\end{array}$ & $\begin{array}{ll}\text { Relax } & \text { Surf } \\
\text { L } & \end{array}$ & $\begin{array}{ll}\text { Relax } & \text { Surf } \\
\text { XL } & \end{array}$ \\
\hline $\begin{array}{l}\text { Monthly } \\
\text { fee } \\
\text { (MKD) }\end{array}$ & $\begin{array}{r}399 \text { den } \\
(6,5 \mathrm{e})\end{array}$ & $\begin{array}{r}599 \text { den } \\
(9,7 \mathrm{e})\end{array}$ & $\begin{array}{r}1199 \\
\operatorname{den}(19,5 \mathrm{e})\end{array}$ & $\begin{array}{r}1799 \text { den } \\
(29,2 \mathrm{e})\end{array}$ \\
\hline $\begin{array}{l}\text { Included } \\
\text { minutes } \\
\text { in same } \\
\text { network } \\
\text { operator }\end{array}$ & $100 \mathrm{~min}$ & $1000 \mathrm{~min}$ & $2000 \mathrm{~min}$ & $3000 \mathrm{~min}$ \\
\hline $\begin{array}{l}\text { Included } \\
\text { internet }\end{array}$ & $300 \mathrm{MB}$ & $1 \mathrm{~GB}$ & $2 \mathrm{~GB}$ & $3 \mathrm{~GB}$ \\
\hline $\begin{array}{l}\text { Included } \\
\text { minutes } \\
\text { in other } \\
\text { networks }\end{array}$ & I & 1 & I & $400 \mathrm{~min}$ \\
\hline $\begin{array}{l}\text { Price per } \\
\text { minute in } \\
\text { all } \\
\text { network } \\
\text { after } \\
\text { exceeding } \\
\text { the } \\
\text { included } \\
\text { minutes }\end{array}$ & $\begin{array}{r}5,9 \\
\mathrm{den} / \mathrm{min} \\
(0,1 \mathrm{e} / \mathrm{min})\end{array}$ & $\begin{array}{r}4,9 \\
\mathrm{den} / \mathrm{min} \\
(0,08 \mathrm{e} / \mathrm{min})\end{array}$ & $\begin{array}{l}3,9 \mathrm{den} / \mathrm{min} \\
(0,06 \mathrm{e} / \mathrm{min})\end{array}$ & $\begin{array}{l}2,9 \mathrm{den} / \mathrm{min} \\
(0,04 \mathrm{e} / \mathrm{min})\end{array}$ \\
\hline
\end{tabular}

Recommendations for better development and improved quality of the mobile services 
The major element of the market economy is free and effective competition. There is no market economy without competition and no competition without a market economy.

The Market competition is simple and effective tool and it ensures that the products and services offered to the consumers are with excellent quality and have competitive prices. The Competition and the free markets are the main power of the productivity, the efficiency, the product development, the innovation and an appropriate defining of the prices. The Competitive markets encourage better technologies and technological development in order to provide high-quality products and services to the customers with prices which are reflection to the costs of efficient producers.

It is a fact that the development of the mobile applications offering free Internet voice communication suppresses the voice traffic in any situation, whether it is in the network of the operator, including the operators in Macedonia or out of the borders of Macedonia. The same happens with messages. In this part, there is a huge reduction in the generated revenues. For these reasons, it is needed to join individual mobile services in packets of services and these packets of services would be more profitable for the operators and more attractive for the users.

It even goes so far that all these packages of services are offered with good electronic equipment such as: good mobile phone, TV sets, PC's, Laptops, tablets, etc. This type of equipment is offered with several monthly repayments, which means that the equal monthly part of the cost of the equipment taken is added to the already defined monthly cost of the package.

There is no doubt that it is necessary and important for an operator to invest and develop its own network. The quality of the service offered to the customers affects the customer satisfaction and in their further using the services from the same operator. Every user wants quality of service and proper price for it. Invested versus received is a master key in the customers and the economic world.

\section{Conclusion:}

The terms in the telecommunications market in Macedonia are in accordance with EU recommendations and ITU. Nowadays, the market is liberalized with 2 mobile operators of public communication networks and 1 mobile virtual operator. They work well in the line of their financial reports. In that context, the market is developed and it follows the technical and technological development in the European and global significance. The Republic of Macedonia with 2 mobile operators and the third mobile virtual operator (LajkaMobajl LLC Skopje) has excellent prospects in this direction and potential providing low-cost services to the users, which are actually the recommendations and objectives from the EU and ITU. With 2.3 million users, and 2 million people, all this shows that telecommunication services in Macedonia have high quality and the prices tend to be lower. They are currently among the lowest in the region and in Europe. The people in Macedonia are expecting higher quality and lower prices of the electronic communication services with the performance of the third virtual operator at the mobile market.

\section{References:}

1. www.aec.mk

2. Agency for electronic communications, Final Document of market analysis for 2014; 2015;

3. Law for Electronic Communications (Official Gazette, 13/2005, 14/2007, 55/2007, 98/2008, 83/10, and 13/12); 2012.

4. Magyar Telekom 2014 financial results report, 
Analysis of the Mobile Market in 2014 in Macedonia, Recommendations for Better Development and Improved Quality of Mobile Services

5. http://www.telekom.hu/static/sw/download/2014_financialyear.pdf

6. Telekom Austria Group Annual Report 2014,

7. http://www.telekomaustria.com/dateien/TAG_AnnualReport_2014.pdf

8. Telekom Slovenia Group Annual Report 2014,

http://www.telekom.si/aboutcompany/annualreports/TS-2014-ENG-PDF-140612LINK.pdf 